\title{
BODY COMPOSITION AND NUTRITION OF FEMALE ATHLETES
}

\author{
Karol Pilis ${ }^{1}$, Krzysztof Stec ${ }^{1}$, Anna Pilis ${ }^{1}$, Agata Mroczek², Cezary Michalskil, Wiestaw Pilis ${ }^{1,2}$
}

${ }^{1}$ Institute of Physical Education, Tourism and Physiotherapy, Jan Dlugosz University, Czestochowa, Poland ${ }^{2}$ Department of Physiotherapy, Opole Medical School, Opole, Poland

\begin{abstract}
Background. The somatic features of the athletes' bodies partially determine their sporting level and are conditioned to a large extent by the state of nutrition.

Objective. The aim of this paper is to present nutritional status and its correlation with the somatic determinants of training athletes and physical education students.

Material and methods. This study involved 12 weightlifting players (subgroup-WL), 15 soccer players (subgroup-SP), 12 table tennis players (subgroup-TT) and 12 female students of physical education (subgroup-C). In all subjects, the age and somatic variables were recorded and the daily intake of energy, water, proteins, fats and carbohydrates was determined by 24-h dietary recalls.

Results. Although the analysis of variance did not show significant differences in somatic variables and nutrition data, post hoc analysis showed significant differences between some subgroups in terms of age, BMI, fat content (BF), fat-free mass (FFM) and the amount of water, protein and carbohydrates consumed during the day. It was also shown that somatic variables correlated with relatively expressed amounts of energy, proteins and carbohydrates consumed in individual subgroups, as well as in the whole group formed from all subgroups of studied women. In addition, there were significant correlations between somatic variables and the total amount of water consumed in the whole group and the total amount of protein consumed in subgroup $\mathrm{C}(\mathrm{p}<0.05)$, as well as the total amount of fat consumed in subgroup WL.

Conclusions. In summary, it was found that the examined women used an abnormal hypoenergetic diet with too low carbohydrate content in which were more useful relative than absolute amounts of consumed proteins, fats and carbohydrates. In this unfavorable situation, dietary education of the respondents seems to be necessary.
\end{abstract}

Key words: body composition, nutrition, women, athletes

\section{STRESZCZENIE}

Wprowadzenie. Cechy somatyczne organizmu sportowca częściowo determinują jego poziom sportowy i są uwarunkowane w znacznym stopniu stanem odżywienia.

Cel. Celem prezentowanej pracy jest przedstawienie stanu odżywienia i jego współzależności z somatycznymi uwarunkowaniami trenujących sportsmenek i studentek wychowania fizycznego.

Materiał i metody. Badaniom poddano 12 zawodniczek podnoszących ciężary (podgrupa- WL), 15 piłkarek nożnych (podgrupa- FP), 12 tenisistek stołowych (podgrupa- TT) oraz 12 studentek wychowania fizyczngo (podgrupa- C). U wszystkich badanych zarejestrowano wiek i zmienne somatyczne oraz określono dobową ilość przyjmowanej energii, wody, białek, tłuszczów i węglowodanów z zastosowaniem techniki 24 h rejestracji wstecznej.

Wyniki. Pomimo, że analiza wariancji nie wykazała istotnych różnic w zakresie zmiennych somatycznych i danych żywieniowych to $\mathrm{w}$ analizie post hoc wykazano występowanie istotnych różnic pomiędzy niektórymi podgrupami w zakresie: wieku, wskaźnika BMI, zawartości tłuszczu (BF), beztłuszczowej masy ciała (FFM) oraz ilości wody, białka i węglowodanów spożywanych w ciągu doby. Wykazano też, że zmienne somatyczne korelowały z względnie wyrażonymi ilościami spożywanej energii, białek i węglowodanów w poszczególnych podgrupach, jak i w całej grupie utworzonej ze wszystkich podgroup badanych kobiet. Ponadto wystąpiły istotne korelacje pomiędzy zmiennymi somatycznymi a globalną ilością spożywanej wody w całej grupie oraz globalną ilością spożywanego białka w podgroupie $\mathrm{C}(\mathrm{p}<0.05)$, jak i globalną ilością spożywanego tłuszczu w podgroupie WL.

Wnioski. Reasumując, stwierdzono, że badane kobiety stosowały nieprawidłową hipoenergetyczną dietę o zbyt małej zawartości węglowodanów w kontroli której bardziej przydatne były relatywne niż absolutne ilości spożywanych białek, tłuszczów i węglowodanów. W tej niekorzystnej sytuacji edukacja dietetyczna badanych wydaje się być konieczna.

Słowa kluczowe: skład ciała, odżywianie, kobiety, sportowcy

Corresponding author: Karol Pilis, Institute of Physical Education, Tourism and Physiotherapy, Jan Dlugosz University, Waszyngtona str. 4/8, 42-200 Częstochowa, Poland, phone: + 48508204 403, +48 3436559 83; e-mail: k.pilis@ujd.edu.pl

(C) Copyright by the National Institute of Public Health - National Institute of Hygiene 


\section{INTRODUCTION}

Nutrition in competitive sports is an important element in the preparation of athletes and has its specificity depending on the type of sport. In endurance sports, more carbohydrates and water are consumed, and in strength sports, the consumption of more proteins is characteristic [7]. In soccer, both aerobic and anaerobic sources of energy supply are stimulated [1]. Hence, in the energy demand of soccer players, the important role is played by carbohydrates, the content of which reaches 5-7 g/kg of body weight under training conditions, and during sports competitions even up to $10 \mathrm{~g} / \mathrm{kg}$ [24]. Often, soccer players do not pay enough attention to the proper diet. And so Ruiz et al. [33] presented an incorrect soccer diet with the following composition: $17.0 \%$ protein, $46.0 \%$ carbohydrates, and $37.0 \%$ fat. It should also be noted that training and soccer matches are played in various weather conditions and for 90 minutes duration of the match, especially at high ambient temperature, the water intake increases significantly and thus prevents the dehydration of the body [23].

There are divergent opinions about the amount of energy ingredients consumed in strength sports [3, 12]. On the other hand, there are opinions regarding the increased amount of protein consumed in these types of sports [9].

Such differentiation in the amount of energy components accepted might affect the somatic conditions of the tested athletes, which have a strong relationship with the achieved sport level [28]. If, in addition, the various impact of weight training in weight lifting and speed and endurance training characterizing soccer are taken into account, as well as specific phosphagen and oxidative training used in table tennis, then one can expect the adaptive differences in the body and somatic conditions between people representing these types sports [26, 20, 21]. Therefore, the presented work shows the composition of used diets and their relationship with the somatic variables of female weightlifters, soccer players and table tennis players against the background of physical education students of similar age.

\section{MATERIAL AND METHODS}

51 women, including 12 weightlifters (WL), 15 soccer players (SP), 12 table tennis players (TT) and 12 women from the control subgroup (C) were examined. Each of the surveyed women were over 18 years old and none of them exceeded the age of 25 . The sportswomen of the three subgroups represented the level II and higher sports classes. All women from C subgroup were students of physical education and lived in a student's hostel. Out of subgroup WL, 3 women lived in the student's hostel and 3 of them were students at the physical education department. In subgroups SP and TT, these numbers were: 5, 7 and 4, 3 respectively. At the beginning, age and basic somatic data were defined for all subjects, including the body height (BH) using an anthropometer, body mass (BM) and body composition with respect to fat content (BF), fat-free mass (FFM) and total water content (TBW) were determined using body fat analyzer Tanita TBF 300A, Japan, with the electrical bio-impedance method. The BMI index was also calculated.

Evaluation of energy and nutrients intake was performed by 24-h dietary recalls, which were collected for 3 selected days. The amount of consumed foods was estimated by using photographs from the book „Album of photograph of food products and dishes" [34]. Calculation of daily intake of energy, water, proteins, fats, and carbohydrates were made with Polish professional software Diet-5. The results were subjected to statistical analysis. Descriptive statistics (mean, standard deviation) were calculated. Analysis of variance (ANOVA) and as a post-hoc test NIR was used. The relationship between studied data was determined by calculation Pearson correlation coefficient.

Statistically significant differences were found at the level of $p<0.05$. The software Statistica 13.1 was used for calculations. The approval for conducting the research was obtained from Bioethical Commission at the Jan Dlugosz University in Czestochowa (Poland).

\section{RESULTS}

The applied analysis of variance shows that within the age and individual somatic variables there were no statistically significant differences between the studied women subgroups (Table 1). Nevertheless, post hoc analysis shows that such differences occurred and are related to: age (WL vs. SP, $\mathrm{p}=0.032 ; \mathrm{WL}$ vs. $\mathrm{C}, \mathrm{p}=0.015$ ), BMI (WL vs. $\mathrm{C}, \mathrm{p}=0.044$; TT vs. $\mathrm{C}, \mathrm{p}=0.034$ ), percent and absolute $\mathrm{BF}$ (WL vs. C, $\mathrm{p}=0.043$ ), percentage expressed FFM (WL vs. C, $\mathrm{p}=0.043$; TT vs. $\mathrm{C}, \mathrm{p}=0.033$ ) and percentage expressed TBW (TT vs. C, $\mathrm{p}=0,039$ ).

Also, the analysis of variance did not show statistically significant differences between the studied subgroups of women in terms of the intake amount of energy, water, proteins, fats and carbohydrates (Table 2). However, a post hoc analysis shows that women from C subgroup consumed more water each day $(2644.60 \pm 770.93 \mathrm{~g} / \mathrm{kg})$ than women from SP subgroup $(1901.00 \pm 660.04 \mathrm{~g} / \mathrm{kg})$, which was statistically significant difference $(\mathrm{p}=0.0163)$. In addition, post hoc analysis shows that women from $\mathrm{C}$ subgroup consumed more proteins per day $(1.55 \pm 0.30 \mathrm{~g} / \mathrm{kg})$ than women from TT subgroup $(1.20 \pm 0.33 \mathrm{~g} / \mathrm{kg})$, which was a statistically significant difference $(p=0.0296)$. 
Table 1. Statistical differences of age and somatic variables between investigated weightlifters (WL), soccer players (SP), table tennis players (TT) and women from the control group (C)

\begin{tabular}{|c|c|c|c|}
\hline Variables/F;p & Group & Mean & $\pm \mathrm{SD}$ \\
\hline \multirow{4}{*}{$\begin{array}{c}\text { Age }[1] \\
\mathrm{F}=2.570 ; \mathrm{p}=0.065\end{array}$} & WL & 19.33 & 1.72 \\
\hline & SP & 21.27 & 2.69 \\
\hline & TT & 21.17 & 2.21 \\
\hline & $\mathrm{C}$ & 21.67 & 2.19 \\
\hline \multirow{4}{*}{$\begin{array}{l}\text { Body height }[\mathrm{cm}] \\
\mathrm{F}=0.305 ; \mathrm{p}=0.821\end{array}$} & WL & 164.50 & 8.05 \\
\hline & SP & 165.53 & 6.02 \\
\hline & TT & 166.92 & 8.09 \\
\hline & $\mathrm{C}$ & 166.58 & 5.11 \\
\hline \multirow{4}{*}{$\begin{array}{l}\text { Body weight }[\mathrm{kg}] \\
\mathrm{F}=0.922 ; \mathrm{p}=0.437\end{array}$} & WL & 61.58 & 9.81 \\
\hline & SP & 60.03 & 8.92 \\
\hline & TT & 60.63 & 7.96 \\
\hline & $\mathrm{C}$ & 56.32 & 5.91 \\
\hline \multirow{4}{*}{$\begin{array}{c}\text { BMI }\left[\mathrm{kg} / \mathrm{m}^{2}\right] \\
\mathrm{F}=1.903 ; \mathrm{p}=0.141\end{array}$} & WL & 22.74 & 3.35 \\
\hline & SP & 21.84 & 2.58 \\
\hline & $\mathrm{TT}$ & 21.75 & 2.49 \\
\hline & $\mathrm{C}$ & 20.26 & 1.64 \\
\hline \multirow{4}{*}{$\begin{array}{c}\text { Fat }[\%] \\
\mathrm{F}=2.050 ; \mathrm{p}=0.119\end{array}$} & WL & 25.43 & 6.91 \\
\hline & SP & 24.35 & 7.23 \\
\hline & TT & 25.74 & 5.95 \\
\hline & $\mathrm{C}$ & 19.92 & 5.69 \\
\hline \multirow{4}{*}{$\begin{array}{c}\text { Fat }[\mathrm{kg}] \\
\mathrm{F}=1.904 ; \mathrm{p}=0.141\end{array}$} & WL & 16.20 & 6.26 \\
\hline & SP & 15.18 & 6.09 \\
\hline & TT & 16.03 & 5.58 \\
\hline & $\mathrm{C}$ & 11.45 & 3.95 \\
\hline \multirow{4}{*}{$\begin{array}{l}\text { Free fat mass }[\%] \\
F=1.904 ; p=0.141\end{array}$} & WL & 74.55 & 6.90 \\
\hline & SP & 75.65 & 7.20 \\
\hline & TT & 74.23 & 5.95 \\
\hline & $\mathrm{C}$ & 80.07 & 5.65 \\
\hline \multirow{4}{*}{$\begin{array}{l}\text { Free fat mass }[\mathrm{kg}] \\
\mathrm{F}=0.107 ; \mathrm{p}=0.955\end{array}$} & WL & 45.39 & 4.53 \\
\hline & SP & 44.87 & 3.43 \\
\hline & TT & 44.58 & 2.74 \\
\hline & $\mathrm{C}$ & 44.87 & 3.35 \\
\hline \multirow{4}{*}{$\begin{array}{l}\text { Content of water TBW }[\%] \\
\qquad \mathrm{F}=1.901 ; \mathrm{p}=0.142\end{array}$} & WL & 54.59 & 5.05 \\
\hline & SP & 55.94 & 5.76 \\
\hline & $\mathrm{TT}$ & 54.34 & 4.33 \\
\hline & $\mathrm{C}$ & 58.63 & 4.14 \\
\hline \multirow{4}{*}{$\begin{array}{l}\text { Content of water TBW }[\mathrm{kg}] \\
\qquad \mathrm{F}=0.138 ; \mathrm{p}=0.936\end{array}$} & WL & 33.24 & 3.31 \\
\hline & $\mathrm{SP}$ & 33.15 & 2.48 \\
\hline & TT & 32.64 & 2.02 \\
\hline & $\mathrm{C}$ & 32.85 & 2.46 \\
\hline
\end{tabular}

When the daily value of intake energy was expressed in percentage, then it turned out that women from subgroup C $(21.66 \pm 3.20 \%)$ consumed more proteins than women from TT subgroup (17.67 $\pm 3.31 \%)$ and women from subgroup WL $(17.80 \pm 4.40 \%)$, which in the first case $(p=0.009)$ and in the second case $(\mathrm{p}=0.0122)$ is statistically significant difference. Post hoc analysis also shows that the players from subgroup WL consumed more carbohydrates $(244.1 \pm 51.04 \mathrm{~g})$ than those of from subgroup C (191.87 $\pm 49.62 \mathrm{~g})$ and the difference was at the level $\mathrm{p}=0.0267)$.
It was also shown that in the combined group of women there were no significant relationships between somatic variables and the global amount of energy delivered to the body.

However, BM, percentage and absolute BF, absolute FFM, absolute TBW and BMI correlated significantly statistically in a negative manner with the relative amount of intake energy, as well as with the relative amounts of proteins and carbohydrates supplied. There were also statistically significant positive correlation coefficients between the percentages of FFM, TBW and relative amounts of intake energy, water, proteins and carbohydrates. 
Table 2. Statistical differences in diet content between weightlifters (WL), soccer players (SP), table tennis players (TT) and women from the control group (C)

\begin{tabular}{|c|c|c|c|}
\hline Variables/F;p & Group & Mean & $\pm \mathrm{SD}$ \\
\hline \multirow{4}{*}{$\begin{array}{l}\text { Energy [kcal] } \\
\quad \mathrm{F}=0.655 \\
\mathrm{p}=0.572\end{array}$} & WL & 1832.45 & 334.71 \\
\hline & SP & 1714.49 & 345.24 \\
\hline & TT & 1682.21 & 301.47 \\
\hline & $\mathrm{C}$ & 1610.06 & 204.54 \\
\hline \multirow{4}{*}{$\begin{array}{l}\text { Energy }[\mathrm{kcal} / \mathrm{kg}] \\
\mathrm{F}=0.175 ; \mathrm{p}=0.908\end{array}$} & WL & 29.80 & 7.91 \\
\hline & SP & 28.59 & 8.41 \\
\hline & TT & 29.16 & 8.25 \\
\hline & $\mathrm{C}$ & 28.47 & 5.42 \\
\hline \multirow{4}{*}{$\begin{array}{c}\text { Water }[\mathrm{ml}] \\
\mathrm{F}=1.666 ; \mathrm{p}=0.178\end{array}$} & WL & 2083.47 & 1072.88 \\
\hline & SP & 1901.00 & 660.04 \\
\hline & TT & 2131.23 & 820.35 \\
\hline & $\mathrm{C}$ & 2644.60 & 770.93 \\
\hline \multirow{4}{*}{$\begin{array}{c}\text { Protein }[\mathrm{g}] \\
\mathrm{F}=0.622 ; \mathrm{p}=0.618\end{array}$} & WL & 79.14 & 24.21 \\
\hline & SP & 80.94 & 20.40 \\
\hline & TT & 72.28 & 19.31 \\
\hline & $\mathrm{C}$ & 85.15 & 19.17 \\
\hline \multirow{4}{*}{$\begin{array}{c}\text { Protein }[\mathrm{g} / \mathrm{kg}] \\
\mathrm{F}=0.880 ; \mathrm{p}=0.458\end{array}$} & WL & 1.27 & 0.40 \\
\hline & SP & 1.35 & 0.38 \\
\hline & TT & 1.20 & 0.33 \\
\hline & $\mathrm{C}$ & 1.53 & 0.30 \\
\hline \multirow{4}{*}{$\begin{array}{c}\text { Protein }[\%] \\
\mathrm{F}=1.850 ; \mathrm{p}=0.138\end{array}$} & WL & 17.80 & 4.40 \\
\hline & SP & 19.34 & 3.40 \\
\hline & TT & 17.67 & 3.31 \\
\hline & $\mathrm{C}$ & 21.66 & 3.20 \\
\hline \multirow{4}{*}{$\begin{array}{c}\text { Fat }[\mathrm{g}] \\
\mathrm{F}=0.745 ; \mathrm{p}=0.579\end{array}$} & WL & 55.43 & 11.91 \\
\hline & SP & 54.15 & 12.23 \\
\hline & TT & 54.64 & 11.95 \\
\hline & $\mathrm{C}$ & 52.11 & 10.69 \\
\hline \multirow{4}{*}{$\begin{array}{c}\text { Fat }[\%] \\
\mathrm{F}=1.741 ; \mathrm{p}=0.170\end{array}$} & WL & 27.60 & 5.26 \\
\hline & SP & 28.75 & 6.09 \\
\hline & TT & 29.58 & 6.58 \\
\hline & $\mathrm{C}$ & 29.45 & 5.95 \\
\hline \multirow{4}{*}{$\begin{array}{l}\text { Carbohydrate }[\mathrm{g}] \\
\mathrm{F}=1.677 ; \mathrm{p}=0.197\end{array}$} & WL & 244.41 & 51.04 \\
\hline & SP & 215.64 & 50.76 \\
\hline & TT & 216.66 & 50.11 \\
\hline & $\mathrm{C}$ & 191.87 & 49.62 \\
\hline \multirow{4}{*}{$\begin{array}{c}\text { Carbohydrate }[\mathrm{g} / \mathrm{kg}] \\
\mathrm{F}=0.830 ; \mathrm{p}=0.461\end{array}$} & WL & 3.96 & 1.28 \\
\hline & SP & 3.59 & 1.11 \\
\hline & TT & 3.53 & 1.08 \\
\hline & $\mathrm{C}$ & 3.44 & 1.15 \\
\hline \multirow{4}{*}{$\begin{array}{l}\text { Carbohydrate }[\%] \\
\qquad \begin{array}{c}\mathrm{F}=0.975 \\
\mathrm{p}=0.395\end{array}\end{array}$} & WL & 54.59 & 8.53 \\
\hline & SP & 51.58 & 8.72 \\
\hline & TT & 52.80 & 7.65 \\
\hline & $\mathrm{C}$ & 48.84 & 6.01 \\
\hline
\end{tabular}

In addition, there were significant negative correlations between body mass $(\mathrm{r}=-0.321, \mathrm{p}<0.05)$, percent $(\mathrm{r}=-0.363, \mathrm{p}<0.01)$, absolute $(\mathrm{r}=-0.380 ; \mathrm{p}<0.01)$ body fat and the amount of intake water.

In the individual subgroups, somatic and dietary relationships occurred with varying frequency (Table 4). The relationships between somatic and relative to body weight as well as the carbohydrate intake percentage were observed in all subgroups of subjects. Significant correlations of somatic variables with relative amounts of intake energy were found in all subgroups of athletes. 
Table 3. Correlation coefficients between somatic variables and nutritional ingredients for all women $(\mathrm{n}=51)$

\begin{tabular}{|c|c|c|c|c|}
\hline Variables & Energy $[\mathrm{kcal} / \mathrm{kg}]$ & $\mathrm{H}_{2} \mathrm{O}[\mathrm{ml}]$ & Protein $[\mathrm{g} / \mathrm{kg}]$ & Carbohydrate $[\mathrm{g} / \mathrm{kg}]$ \\
\hline BM $[\mathrm{kg}]$ & $-0.5004 * * *$ & $-0.3209 *$ & $-0.5150 * * *$ & $-0.4936 * * *$ \\
\hline BH $[\mathrm{cm}]$ & -0.1910 & -0.1716 & -0.2446 & -0.1934 \\
\hline BF $[\%]$ & $-0.4350 * *$ & $-0.3628 * *$ & $-0.4564 * * *$ & $-0.4162 * *$ \\
\hline BF $[\mathrm{kg}]$ & $-0.4793 * * *$ & $-0.3802 * *$ & $-0.5021 * * *$ & $-0.4649 * * *$ \\
\hline FFM $[\%]$ & $0.4353 * *$ & $0.3624 * *$ & $0.4565 * * *$ & $-0.4162 * *$ \\
\hline FFM $[\mathrm{kg}]$ & $-0.4103 * *$ & -0.1432 & $-0.4074 * *$ & $0.4396 * *$ \\
\hline TBW $[\%]$ & $0.4910 * * *$ & $0.3771 * *$ & $0.5118 * * *$ & $-0.3804 * *$ \\
\hline TBW $[\mathrm{kg}]$ & $-0.3370 *$ & -0.1158 & $-0.3337 * *$ & $-0.4537 * * *$ \\
\hline BMI $\left[\mathrm{kg} / \mathrm{m}^{2}\right]$ & $-0.4692 * * *$ & -0.2504 & $-0.4311 * *$ & \\
\hline
\end{tabular}

${ }^{*} \mathrm{p}<0.05 ; * * \mathrm{p}<0.01 ; * * * \mathrm{p}<0.001$

Table 4. Correlation coefficients of somatic variables and energy, proteins, fat and carbohydrates intake for all subgroups

\begin{tabular}{|c|c|c|c|c|c|c|c|c|c|}
\hline Variables & $\begin{array}{l}\mathrm{BM} \\
{[\mathrm{kg}]}\end{array}$ & $\begin{array}{c}\mathrm{BH} \\
{[\mathrm{cm}]}\end{array}$ & $\begin{array}{l}\mathrm{BF} \\
{[\%]}\end{array}$ & $\begin{array}{l}\mathrm{BF} \\
{[\mathrm{kg}]}\end{array}$ & $\begin{array}{c}\text { FFM } \\
{[\%]}\end{array}$ & $\begin{array}{l}\text { FFM } \\
{[\mathrm{kg}]}\end{array}$ & $\begin{array}{c}\text { TBW } \\
{[\%]}\end{array}$ & $\begin{array}{l}\text { TBW } \\
{[\mathrm{kg}]}\end{array}$ & $\begin{array}{c}\text { BMI } \\
{\left[\mathrm{kg} / \mathrm{m}^{2}\right]}\end{array}$ \\
\hline $\begin{array}{c}\text { Energy } \\
{[\mathrm{kcal} / \mathrm{kg}]}\end{array}$ & $\begin{array}{c}-0.622^{\mathrm{a}} \\
-0.667^{\mathrm{b}} \\
\mathrm{NS}\end{array}$ & $\begin{array}{c}\mathrm{NS} \\
-0.767^{\mathrm{b} b} \\
\mathrm{NS}\end{array}$ & $\begin{array}{c}\mathrm{NS} \\
-0.615^{\mathrm{b}} \\
-0.586^{\mathrm{c}}\end{array}$ & $\begin{array}{c}\mathrm{NS} \\
-0.650^{\mathrm{b}} \\
-0.584^{\mathrm{c}}\end{array}$ & $\begin{array}{c}\mathrm{NS} \\
-0.604^{\mathrm{b}} \\
0.586^{\mathrm{c}}\end{array}$ & $\begin{array}{c}\mathrm{NS} \\
-0.772^{\mathrm{b} b} \\
\mathrm{NS}\end{array}$ & $\begin{array}{c}\mathrm{NS} \\
\mathrm{NS} \\
0.589^{\mathrm{c}}\end{array}$ & $\begin{array}{l}\text { NS } \\
\text { NS } \\
\text { NS }\end{array}$ & $\begin{array}{c}\mathrm{NS} \\
\mathrm{NS} \\
-0.633^{\mathrm{c}}\end{array}$ \\
\hline Proteins $[\mathrm{g}]$ & $\begin{array}{c}0.677^{d} \\
-0.568^{a}\end{array}$ & $\begin{array}{l}\text { NS } \\
\text { NS }\end{array}$ & $\begin{array}{l}0.572^{\mathrm{d}} \\
0.580^{\mathrm{a}}\end{array}$ & $\begin{array}{c}0.651^{\mathrm{d}} \\
-0.608^{a}\end{array}$ & $\begin{array}{c}-0.576^{d} \\
0.580^{a}\end{array}$ & $\begin{array}{c}0.595^{\mathrm{d}} \\
\mathrm{NS}\end{array}$ & $\begin{array}{c}-0.573^{\mathrm{d}} \\
0.583^{\mathrm{a}}\end{array}$ & $\begin{array}{l}\text { NS } \\
\text { NS }\end{array}$ & $\begin{array}{c}0.587^{\mathrm{d}} \\
\mathrm{NS}\end{array}$ \\
\hline Proteins $[\mathrm{g} / \mathrm{kg}]$ & $-0.560^{b}$ & NS & NS & $-0.576^{b}$ & NS & NS & $0.659^{b}$ & NS & NS \\
\hline Fat $[\mathrm{g}]$ & NS & $0.686^{\text {a a }}$ & NS & NS & NS & $0.649^{\mathrm{a}}$ & NS & $0.651^{\mathrm{a}}$ & NS \\
\hline Fat $[\%]$ & $0.583^{\mathrm{a}}$ & NS & NS & NS & NS & $0.692^{\text {a a }}$ & NS & $0.694^{\text {a a }}$ & NS \\
\hline $\begin{array}{c}\text { Carbohydrate } \\
{[\mathrm{g} / \mathrm{kg}]}\end{array}$ & $\begin{array}{l}-0.625^{a} \\
-0.630^{b} \\
-0.554^{c}\end{array}$ & $\begin{array}{c}\mathrm{NS} \\
-0.728^{\mathrm{b} b} \\
\mathrm{NS}\end{array}$ & $\begin{array}{c}\mathrm{NS} \\
-0.589^{\mathrm{b}} \\
-0.625^{\mathrm{c}}\end{array}$ & $\begin{array}{l}-0.553^{a} \\
-0.614^{b} \\
-0.608^{c}\end{array}$ & $\begin{array}{c}\mathrm{NS} \\
0.585^{\mathrm{b}} \\
0.624^{\mathrm{c}}\end{array}$ & $\begin{array}{c}-0.591^{\mathrm{a}} \\
-0.557^{\mathrm{b}} \\
\mathrm{NS}\end{array}$ & $\begin{array}{c}\mathrm{NS} \\
0.676^{\mathrm{b}} \\
0.626^{\mathrm{c}}\end{array}$ & $\begin{array}{c}-0.593^{\mathrm{a}} \\
\mathrm{NS} \\
\mathrm{NS}\end{array}$ & $\begin{array}{c}-0.618^{a} \\
N S \\
-0.686^{c}\end{array}$ \\
\hline $\begin{array}{c}\text { Carbohydrate } \\
{[\%]}\end{array}$ & $\begin{array}{c}-0.703^{\mathrm{d}} \\
\mathrm{NS} \\
-0.663^{\mathrm{d}}\end{array}$ & $\begin{array}{c}-0.566^{\mathrm{d}} \\
\mathrm{NS} \\
\mathrm{NS}\end{array}$ & $\begin{array}{c}\mathrm{NS} \\
\mathrm{NS} \\
-0.553^{\mathrm{d}}\end{array}$ & $\begin{array}{c}\text { NS } \\
\text { NS } \\
-0.620^{d}\end{array}$ & $\begin{array}{c}\mathrm{NS} \\
\mathrm{NS} \\
0.553^{\mathrm{d}}\end{array}$ & $\begin{array}{c}-0.588^{\mathrm{d}} \\
\mathrm{NS} \\
\mathrm{NS}\end{array}$ & $\begin{array}{l}\text { NS } \\
\text { NS } \\
\text { NS }\end{array}$ & $\begin{array}{c}-0.585^{\mathrm{d}} \\
-0.577^{\mathrm{d}} \\
\mathrm{NS}\end{array}$ & $\begin{array}{c}\mathrm{NS} \\
\mathrm{NS} \\
-0.577^{\mathrm{d}}\end{array}$ \\
\hline
\end{tabular}

a - subgroup WL; b - subgroup SP; c - subgroup TT; d - subgroup C

Also, somatic variables correlated significantly with the global and relative amount of intake proteins only in the subgroup of female students in the first case and in subgroups WL and SP in the second case. Significant correlations of somatic variables with global and percentage of fat intake were also observed only in subgroup WL.

\section{DISCUSSION}

Although the analysis of variance did not show significant differences in the BMI index, post hoc analysis showed that subgroup WLachieved significantly higher values of this variable than subgroups $C$ and TT. Unfortunately, higher values of BMI index in the strength-trained group of women did not result in FFM increase and were the expression of higher fat content in this subgroup in relation to subgroup C. It is known that strength training to a greater extent than other types of physical loads leads to higher values of BMI by increasing FFM, mainly in men, but it does not always lead to a significant reduction of BF [27]. This process is less developed in women and in the presented studies, the fat content in WL slightly exceeded the upper physiological tolerance limit for adults, untrained women. In addition, it should be noted that the tested 
WL sportswomen were significantly younger than those from subgroups $\mathrm{C}$ and $\mathrm{SP}$ and for this reason probably did not develop a sufficiently large FFM. The consequence of the different content of adipose tissue in the studied subgroups was the difference between them in the FFM range. Lack of clearly marked somatic adaptive changes in the SP subgroup against the background of other studied women is surprising because modern soccer training contains high loads reaching $90-95 \%$ of the maximum heart rate, as well as significant strength loads generating development of players' power [13]. However, it is necessary to approach this data in a relative manner because the training loads for women are significantly lower than for men. For example, one can compare the training loads in futsal in which men during the match on average run about 4,000 $\mathrm{m}$ [2] while women only about $2,730 \mathrm{~m}$ [4]. It was also found that women's physical performance in soccer depends significantly on the level of $\mathrm{VO}_{2}$ max [19], as well as on the amount of anaerobic power developed in strength and speed training [17].

Therefore, in order to increase the value of this specific physical performance, soccer players should perform endurance, strength and speed training, which should significantly change their body composition. Similarly, lower training loads occur in other types of women's sports in relation to men's physical loads and to a lesser extent modify the somatic conditions of sportswomen. Women who participated in our research represented the average sports level and therefore it should be assumed that these small differences in body composition between the studied subgroups were less modified by the type of applied training and the more important reason underlying these unfavorable changes was the different lifestyle of the individual subgroups. Women included in subgroup WL mostly lived in family homes and 3 of them as students lived in student hostels, about $30 \%$ of women from subgroups SP and TT lived with their families and the remaining part were students living in student hostels. Only about half of the surveyed sportswomen were students of physical education. However, all women from subgroup $\mathrm{C}$ were students of physical education and lived in student hostels, where they adopted a specific lifestyle, including consumption of too few energy components, an incorrect composition of their diet, lack of systematic nutrition, too little sleep or alcohol abuse [14, 29]. Such a lifestyle leads to negative somatic consequences and imitates the obesity process [35]. On the other hand, some of the students were lead to erroneous care for the aesthetics of their own body and it mainly consisted of taking too small amounts of food [15]. In our study, subgroup C cultivated a typical student lifestyle, which was characterized by a tendency to consume smaller amounts of energy ingredients than subgroups WL,
SP as well as TT. Moreover, in subgroup C there was also increased energy expenditure every day, because they were burdened with the obligatory physical activities included in the physical education study program. On the other hand, about half of the surveyed sportswomen were not students from physical education department and they participated in sports trainings most frequently three times per week. Therefore, it should be assumed that the daily energy expenditure of all studied subgroups was at a similar level. Hence, it should be concluded that the significantly lower BMI and fat content in subgroup $\mathrm{C}$ than in subgroups WL and TT demonstrated by the post hoc test are the expression of a different lifestyle of these women, including the wrong diet, which modified their body composition and weight [36]. The small amounts of energy ingredients supplied to the body in all subgroups, i.e. carbohydrates and fats, caused that the global amount of energy delivered in the daily diet was insufficient. It is believed that daily sports' nutrition below $2200 \mathrm{kcal}$ is a low-energy diet [10]. This has been confirmed by Celejowa [7], who has established that the daily energy intake should be 70$77 \mathrm{kcal} / \mathrm{kg} ; 65-70 \mathrm{kcal} / \mathrm{kg} ; 62-69 \mathrm{kcal} / \mathrm{kg}$ in subgroups WL, SP and TT, respectively. This comparison shows that among the trained women and in group $\mathrm{C}$ there was an energy deficit, which has increased by the increased physical activity of these women. This unfavorable phenomenon is also confirmed by the lack of statistically significant correlations between body mass, BMI, other somatic variables and the total amount of energy delivered to the body [16]. In our research, an additional factor modifying the lack of relationships between somatic variables and reduced amount of intake energy ingredients was increased during physical activity but in the case of Pysz et al. [30] it was the accelerated somatic development of 10-12 year old children. It was also observed in our study that under energy deficit conditions there are significant correlations of somatic variables and the relative amount of energy supplied to the body. These correlations occurred most frequently in the combined group of 51 women and in three subgroups of athletes. The lack of these correlations in subgroup $\mathrm{C}$ is difficult to explain, but it is likely that this is due to a significant energy deficit in this subgroup. It should also be mentioned that the BMI index even in the subgroups of athletes is not universally a reliable indicator of post-training somatic adaptation, as it does not always correlate with the size of muscle or bone mass as well as more often with the percentage of fat in the body [11].

In terms of the amount of water consumed, women from individual subgroups differed statistically and the most of it was consumed in subgroup C. It should be recognized that these quantities were physiologically 
appropriate and in this context women from the trained subgroups consumed too small volume of water [31, $22,18]$. The calculated correlation coefficients between somatic variables and the global amount of intake water were statistically insignificant in individual subgroups, which may be related to their small number. However, the amount of globally consumed water correlated with somatic variables in the combined group of women (Table 3). In this group, among other things, a negative correlation was found between the size of body weight and the global amount of drinking water, which indicates the above-mentioned too low consumption of water, especially by the trained subgroups. Reflecting such relationships in terms of the amount of consumed water is the tendency to appear larger relative TBW values, especially in subgroup $C$.

If the relative amount of intake proteins taken into consideration, it turned out that in all subgroups it was correct and exceeded $1 \mathrm{~g} / \mathrm{kg}$. However, after taking into account the increased physical activity of the studied women, the best values were observed in subgroup C. The global content of these ingredients in the diet of women from subgroup $\mathrm{C}$ correlated positively with body weight and other somatic conditions, as in Pysz et al., study [30]. Similar correlations occurred in relation to FFM, BMI and other somatic variables (Table 4). It is also known that the correct amount of consumed protein is used for more intensive muscle recovery, which increases the amount of FFM and the accompanying increased water content in the body [6]. These processes were visible in subgroup $\mathrm{C}$ in which the percentages of FFM and TBW shows an upward trend with respect to the other subgroup. However, in the combined group of studied women there were no significant correlations of somatic variables and global protein intake, which may indicate that under the conditions of low energy diet, increased physical activity disturbs the occurrence of such relationships, which may be due to insufficient protein intake under these conditions. In addition, the relative amounts of intake proteins correlated with somatic variables in subgroups WL and SP, as well as in the entire combined group of women, which indicates the important role of proteins in the somatic structure of body and stress the use of such a relative indicator in the assessment of somatic interdependencies.

The percentage of intake fat by the examined women appears to be correct and was similar in all subgroups. However, taking into account the fact that the energy value of used diets is significantly lower then the amount of intake fat may turn out to be too low. The lack of correlation between global and relative amounts of intake fat and somatic variables in the combined group of women, as well as in subgroups SP, TT and C may indicate a less significant importance of these dietary ingredients in modifying somatic conditions. On the other hand, the positive correlation of BM, FFM and TBW with the global and percentage of fat provided in the diet WL suggests that the lack of fat in this group of women did not occur, or was tolerated, or was compensated in another way.

The studied groups differed in the amount of carbohydrates in the diet and its relative intake was too low in all subgroups under the conditions of increased physical activity $[5,18,25]$. The lack of significant correlations between somatic and total as well as the percentage amount of intake carbohydrates allows concluding that these ingredients is deficient in the applied diets and/or it suggest uselessness of both carbohydrate indicators in the assessment of somatic conditions of the body. However, relative to body weight, the amount of intake carbohydrates correlated with the somatic variables of all subgroups and the combined group, which underlines the effectiveness of this indicator in the assessment of the somaticnutritional relationship of the subjects.

The analysis shows that the surveyed women did not eat properly and therefore the impact of their diets on the somatic variables were not always correctly reflected. This erroneous combination of diets in the individual subgroups confirms the recommendation of Celejowa [7], which suggests that the proportions of proteins, fats and carbohydrates, appropriate in athletes', weightlifters, soccer and table tennis players diets should be shaped in the following proportions: $14 \%, 31 \%, 55 \%$; 14\%, 29\%, 57\%; 14\%, 29\%, 57\%.

In the case of people examined in this study, the obtained values were different from the recommended ones and amounted respectively to:

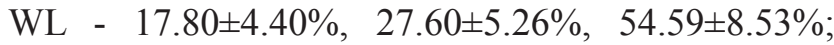
SP - $19.34 \pm 3.40 \%, 28.75 \pm 6.09 \%, 51.58 \pm 8.72 \%$; and TT $-17.67 \pm 3.31 \%, 29.58 \pm 6.58 \%, 52.80 \pm 7.65 \%$. This abnormal nutritional tendency was also observed by other authors, both in training and inactive people, who observed additional nutritional mistakes such as excessive consumption of simple sugars, low fiber intake or excessive micronutrient supplementation $[8$, 32]. Apart from improper nutrition, too low intensity of applied training, not differing from the physical loads of students of physical education, resulted in only slight somatic modifications in case of the examined women.

\section{CONCLUSIONS}

1. An abnormal, hypoenergetic diet with insufficient water and carbohydrate content used in conditions of increased physical activity, combined with a specific lifestyle, only slightly modified the somatic parameters of the body.

2. Global amounts of consumed energy, proteins, fats and carbohydrates incorrectly or not at all reflect 
the somatic determinants of the body of physically active women in conditions of negative energy balance.

3. A good indicator of somatic and nutritional relations of physically active women in the conditions of a negative energy balance appear to be the relatively expressed amounts of intake energy, proteins, fats and carbohydrates.

4. In the unfavorable nutritional situation of the surveyed women, their dietary education seems to be necessary.

\section{Conflict of interest}

The authors declare no conflict of interest.

\section{REFERENCES}

1. Bangsbo J., Mohr M., Krustrup P.: Physical and metabolic demands of training and match play in the elite football player. J Sports Sci 2006;24:665-674.

2. Barbero-Alvarez J.C., Soto V.M., Barbero-Alvarez V., Granda-Vera J.: Match analysis and heart rate of futsal players during competition. J Sports Sci 2008;26:63-73.

3. Bazzarre T.L., Kleiner S.M., Litchword M.D.: Nutrient intake, body fat, and lipid profiles of competitive male and female bodybuilders. J Am Coll Nutr 1990;9(2):136142.

4. Beato M., Coratella G., Schena F., Hulton A.T.: Evaluation of the external and internal workload in female futsal players. Biol Sport 2017;43(3):227-231.

5. Burke L.M., Loucks A.B., Broad N.: Energy and carbohydrate for training and recovery. J Sports Sci 2006;24:675-685.

6. Campos G.E., Luecke T.J., Wendeln H.K., Toma K., Hagerman F.C., Murray T.F., Ragg K.E., Ratamess N.A., Kraemer W.J., Staron R.S.: Muscle adaptations in response to three different resistance training regimens: specificity of repetiotion maximum training zones. Eur J Appl Physiol 2002;88(1-2):50-60.

7. Celejowa I.: Żywienie w sporcie. [Nutrition in sport]. Warszawa, PZWL, 2008 [in Polish].

8. Czeczelewski J., Raczyński G.: Nutritional status versus diet composition of 10-15 year-old children from the Central-East Poland. Pol J Food Nutr Sci 2006;15(2):221-226.

9. Dragan G.L., Vasiliu A., Georgescu E.: Effect of increased supply on protein on elite weight lifters. In: Galesloot T.E., Tinbergen B.J. eds. Milk protein. Wageningen, The Nederlands, Pudoc, 1985;99-103.

10. Economos C.D., Bortz S.S., Nelson M.E.: Nutritional practices of elite athletes. Practical recommendations. Sports Med 1993;16(6):381-399.

11. Garrido-Chamorro R.P., Sirvent-Belando J.E., Gonzalez-Lorenzo M., Martin-Carratola M.L., Roche E.: Correlation between body mass index and body composition in elite athletes. J Sports Med Phys Fitness 2009;49(3):278-284.
12. Heinemann L., Zerbes H.: Physical activity, fitness, and diet: Behavior in the population compared with elite athletes in the GDR. Am J Clin Nutr 1989;49:10071016.

13. Hoff J., Helgerud J.: Endurance and strength training for soccer players: physiological considerations. J Sports Med Phys Fitness 2006;46(4):520-525.

14. Keller S., Maddock J.E., Hannöver W., Thyrian J.R., Basler H.D.: Multiple health risk behaviors In German first year university students. Prev Med 2008;46(3): 189-195. DOI:10.1016/j.ypmed.2007.09.008.

15. Kęska A., Lutosławska G., Mazurek K., Czajkowska A., Tkaczyk J., Iwańska D.: Changes in anthropometry and selected metabolic parameters in young men during their first year os study at a university of physical education. Am J Mens Health 2018;12(2):463-471.

16. Kęska A., Sobczak M., Lutosławska G., Mazurek K., Tkaczyk J., Kłos A., Bertrandt J.: Indices of body composition, energy and macronutrient intakes in young men and women with different physical activity. J Pre-Clin Clin Res 2013;7(1):36-39.

17. Laird R.H. 4th, Elmer D.J., Barberio M.D., Salom L.P., Lee K.A., Pascoe D.D.: Evaluation of performance improvements after either resistance training or sprint interval-based concurrent training. J Strength Cond Res 2016;30(11):3057-3065.

18. Maughan R.J., Shirreffs S.M.: Nutrition and hydration concerns of the female all player. $\mathrm{Br} \mathrm{J}$ Sports Med 2007;41:60-63.

19. McCormack W.P., Stout J.R., Wells A.J., Gonzales A.M., Mangine G.T., Fragala M.S., Hoffman J.R.: Predictors of high-intensity running capacity in collegiate women during a soccer game. J Strength Cond Res 2014;28(4):964-970. DOI: 10.1519/ JSC.0000000000000359.

20. Milanović Z., Pantelić S., Sporiš G., Moth M., Krustrup $P$.: Health-related physical fitness in healthy untrained men: effects of $\mathrm{VO}_{2}$ max jump performance and flexibility of soccer and moderate-intensity continuous running. PLOS ONE 2015;10(8): e0135319,1-14. DOI:101371/journal. pone.0135319.

21. Milioni F., Vieira de Mello Leite J., Beneke R., Bonetti de Poli R.A., Papoti M, Zagatto A.M.: Table tennis playing styles require specific energy systems. PLoS ONE 2018;13(7). DOI: 10.1371/journal.pone.0199985.

22. National Research Council, Recommended Dietary Allowances. DC Press, National Academy, Washington, 1989, 249.

23. Noakes T.D., Goodwin N., Rayner B.L., Branken T., Taylor N.K.N.: Water intoxication: A possible complication during endurance exercise. Med Sci Sports Exerc 1985; 17:370-375.

24. Nutritional for football: the FIFA/F-MARC Consensus Conference. J Sports Sci 2006;24(7):663-664.

25. Onywera V.O., Kiplamai F.K., Boit M.K., Pitsiladis Y.P.: Food and macronutrient intake of elite kenyan distance runners. Int J Sport Nutr Exerc Metab 2004;14:709-719.

26. Pilis K., Michalski C., Zych M., Pilis A., Jelonek J., Kaczmarzyk A., Pilis $W .:$ A nutritional evaluation of dietary behavior in various professional sports. Rocz Państw Zakl Hig 2014;65(3):227-234. 
27. Pilis W., Langfort J., Zarzeczny A., Zajac A., Wojtyna J.: Morphological and physiological characteristics of top weight lifters. Biol Sport 1990;7(2):113-128.

28. Pilis W., Wojtyna J., Langfort J., Zajacc A., Manowska B., Chmura J., Zarzeczny R.: Relationships between sport results, somatic variables and anaerobic power in elite weight lifters. Biol Sport 1997;14(4):275-281.

29. Poortinga $W$ : The prevalence and clustering of four major lifestyle risk factors in an English adult population. Prev Med 2007;44(2):124-128. DOI: 10.1016/j.ypmed.2006.10.006.

30. Pysz M., Leszczyńska T., Cieślik E.. Kopeć A., Wielgos B., Piatkowska E.: Relationship between the intake of energy and basic nutrients and the BMI values in the group of children aged 10-12. Rocz Panstw Zakł Hig 2014;65(4):345-352.

31. Rodriguez N.R., Di Marco N.M., Langley S.: American College of Sports Medicine position stand. Nutrition and athletic performance. Med Sci Sports Exerc 2009;41:709-73.
32. Ronsen O., Sungot-Borgen J., Maehlum S.: Supplement use and nutritional habits in Norwegian elite athletes. Scand J Med Sports 1999;9(1):28-35.

33. Ruiz F., Irazusta A., Gil S., Irazusta J., Casis L., Gil J.: Nutritional intake in soccer players of different ages. $J$ Sports Sci 2005;23(3):235-242.

34. Szponar L., Wolnicka K., Rychlik E.: Album fotografii produktów i potraw [Album of photographs of food products and dishes]. Institute of Food and Nutrition, Warsaw 2000 [in Polish].

35. Wengreen H.J., Moncur C.: Change in diet, physical activity, and body weight among young-adults during thetransition from high school to collage. Nutr J 2009;8:32. DOI: 10.1186/1475-2891-8-32.

36. Zinn C., Wood M., Williden M., Chatterton S., Maunder $E$.: Ketogenic diet benefits body composition and wellbeing but not performance in a pilot case study of New Zealand endurance athletes. J Int Soc Sports Nutr 2017;14:22. DOI: 10.1186/s12970-017-0180-0.

Received: 19.03.2019

Accepted: 18.06.2019 